\title{
Design of hydraulic concrete compositions design with use of experimental-statistic models
}

\author{
Leonid Dvorkin \\ National University of Water and Environmental Engineering \\ Soborna Street 11, Rivne, Ukraine, 33028 \\ dvorkin.leonid@gmail.com, orcid.org/0000-0001-8759-6318
}

Received 27.05.2019, accepted after revision 06.06.2019

https://doi.org/10.31493/uwt1909.1801

\begin{abstract}
The article discusses the features and general methodological principles for solving problems of multiparameter design of concrete compositions using experimental statistical models obtained using mathematical planning of experiments.

Examples are given of solving problems of optimization of compositions of hydraulic concrete with standardized parameters of strength, frost resistance and water impermeability. Polynomial models of given properties of a concrete mix and concrete are given, depending on the main technological factors, taking into account the characteristics of the initial materials. On the basis of the obtained models, nomograms are constructed that allow performing the necessary technological calculations. Using the above nomograms, the compositions of concrete are calculated, which ensure the specified properties of concrete under conditions of normal hardening and heat treatment. The influence of the duration of hardening and the content of entrained air for concrete of various compositions was determined.
\end{abstract}

Keywords: hydraulic concrete, strength, frost resistance, water impermeability, mathematical models.

Design of concrete compositions is a key technological problem. Its solution defines the level of operational reliability of buildings and structures, and a degree of rational resources use for their manufacturing and construction.

The problems of concrete composition design that were formulated at the early beginning of concrete technologies remains actual in

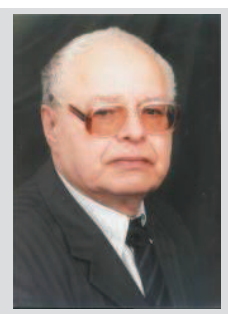

Leonid Dvorkin

Head of building products and materials science department

Dr.Tech.Sc, Prof.

the present time, too. In modern technology, design of concrete compositions means justification and selecting the type of initial materials and their contents, providing the normative concrete mix requirements and hardened concrete properties for a given optimization criterion. Using the system approach methodology for concrete compositions design may include a number of additional problems, associated with technological parameters' and design requirements' optimization.

Presently in technological practice, concrete compositions design is carried out using numerous methods, based on various theoretical and technological preconditions. All of these methods can be successfully used in practice if they solve the required tasks.

Actual directions for developing the methodology of concrete compositions design are:

- increasing the "forecasting ability" of design dependencies, i.e., possibilities of more accurate taking into account of concrete technology factors and design requirements; 
- improving the design algorithms' efficiency, their accuracy and speed.

In construction and technological practice, the most popular are methods of concrete compositions design aimed at receiving the required compressive strength of hardened concrete. It is first of all because concrete strength is its basic parameter. Another reason is the assumption that other concrete properties are also definitely related with compressive strength. This assumption, however, is not common enough. Really, concrete compressive, flexural and tensile strengths as well as its wear and cavitation resistance, etc., are definitely interdependent. However, dependence between strength and frost resistance, strength and creep, etc., are not definite; their determination should be based on using a complex of special quantitative dependences. If it is necessary to achieve some other building and technical properties, in addition to compressive strength, the task of concrete compositions design becomes significantly more complicated.

Design of special concrete type's compositions is a multi-parametric task (MPCCD). The complex of standardized parameters for hydraulic concrete is determined by the massiveness and the working conditions of concrete, taking into account the impact of water - environment. The task of designing the composition of concrete is to select the initial materials and their ratio, providing a set of necessary properties of concrete with a given criterion of optimality, as a rule, the minimum cement consumption or minimum cost. The solution of this task is most expediently performed with the help of experimental statistical models that allow one to quantify the relationship of concrete properties both among themselves and with the main factors affecting them.

\section{INTRODUCTION}

MPCCD tasks differ from traditional by a big number of parameters considered at the "input" as well as an "output" of concrete as complex heterogeneous system. All MPCCD tasks can be divided into two types:

1) compositions problems, aimed at obtaining specific components consumptions, providing the given complex of concrete properties;

2) compositions - technological problems, aimed at finding along with specific components consumptions the values of some technological factors, characterizing the conditions of concrete producing and hardening.

Algorithms of compositions problems (Fig.1) [1-4] suggest finding the basic parameters of the mixture - cement-water ratio $(\mathrm{C} / \mathrm{W})$, water consumption $(\mathrm{W})$, entrained air volume $\left(\mathrm{V}_{\text {air }}\right)$ and portion of sand in the aggregates mix $(r)$, providing the complex of given properties in the most effective manner. Algorithms of compositions -technological problems (Fig.1) suggest finding basic parameters of the mixture as well as technological process parameters $\left(\sum T_{r}\right)$ (temperature, hardening duration, compaction mode, etc.).

Using basic mixture parameters together with equations of absolute volumes allows obtaining consumptions of a 5-component concrete mixture (cement $(\mathrm{C})$, water $(\mathrm{W})$, volume of entrained air $\left(\mathrm{V}_{\text {air }}\right)$, fine $(\mathrm{S})$ and coarse aggregates (Cr.S).

For concrete with admixtures and lightweight concrete it is expediently to use as the core composition parameter the "modified $\mathrm{C} / \mathrm{W}^{\prime}$ [5]. It essentially increases the applicability range of design-experimental methods of concrete proportioning and dependencies for calculating concrete strength.

Selecting quantitative dependencies should consider as the purpose of a specific problem, as available initial information. For example, in simple problems, including finding strength of regular concrete without mineral, air entraining or other admixtures in normal hardening conditions the most known formulas may be used [6]. If detailed information regarding initial materials features is available, coefficients in equations of concrete strength are specified according to appropriate recommendations $[7,8]$. 


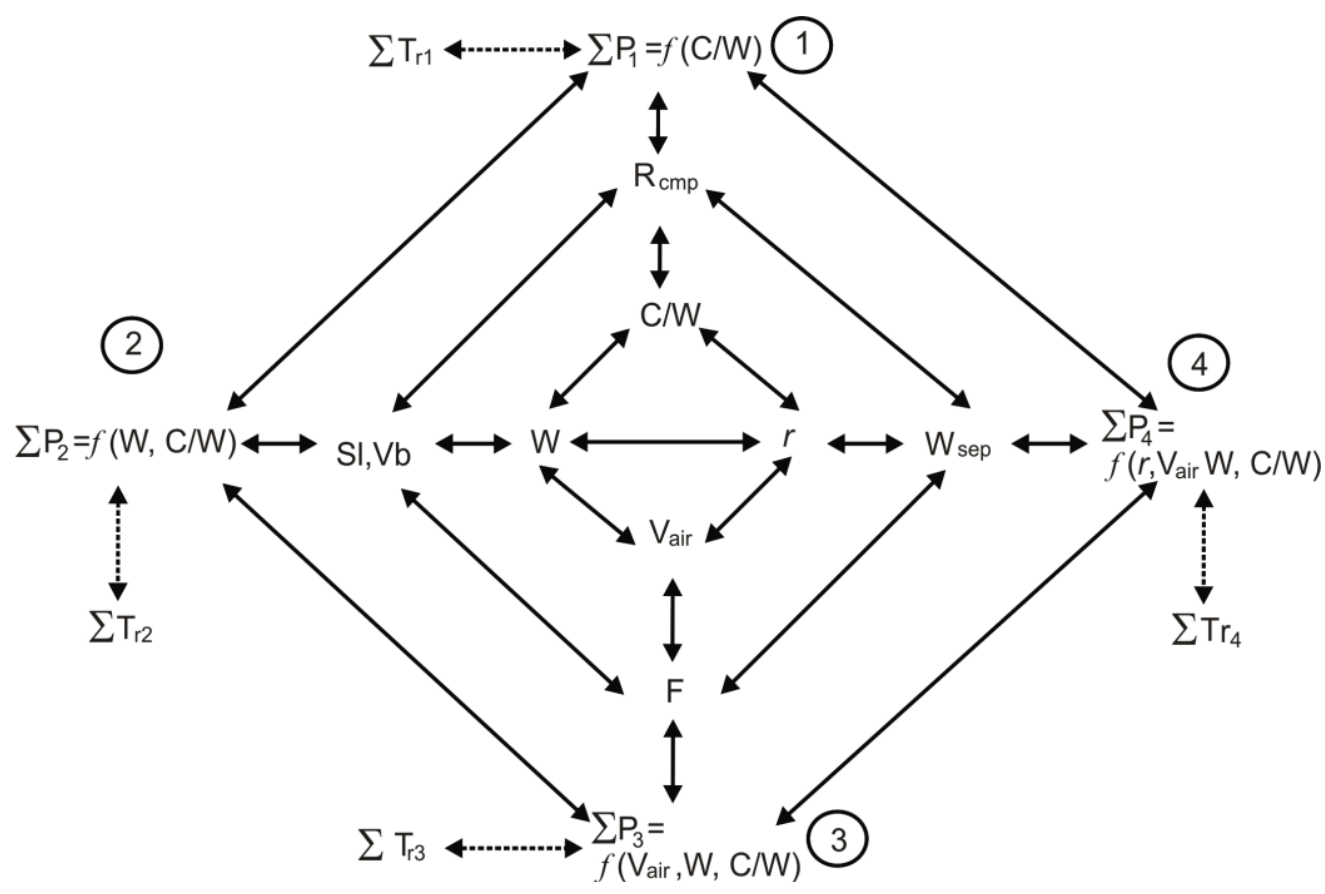

Fig.1. A block scheme for multiparametric concrete proportioning ( $\sum \mathrm{P}-$ a group of concrete properties, related to certain parameters of the mixture, $\Sigma \mathrm{T}_{\mathrm{r}}-$ a group of technological factors, affecting concrete properties). 1. Obtaining compressive strength $\mathrm{R}_{\mathrm{cmp}}$ to achieve $\sum \mathrm{P}_{1}=\mathrm{f}(\mathrm{C} / \mathrm{W})$ and required cement-water ratio C/W. 2. Obtaining the water consumption $\mathrm{W}$ for achieving $\sum \mathrm{P}_{2}=\mathrm{f}(\mathrm{W}, \mathrm{C} / \mathrm{W})$. Sl and $\mathrm{Vb}$ are Slump and Vebe time values, accordingly. 3. Obtaining the entrained air volume $\mathrm{V}_{\text {air }}$ for achieving $\sum \mathrm{P}_{3}=\mathrm{f}\left(\mathrm{V}_{\text {air }}, \mathrm{W}, \mathrm{C} / \mathrm{W}\right)$.

4. Obtaining parameter $\mathrm{r}$ for achieving $\sum \mathrm{P}_{4}=\mathrm{f}\left(\mathrm{r}, \mathrm{V}_{\text {air }}, \mathrm{W}, \mathrm{C} / \mathrm{W}\right)$. $\mathrm{W}_{\text {sep }}$ is the water separation value.

Various quantitative dependences can be used also for obtaining aggregates consumption. At known aggregates specific surface and voidage values it is possible to use a formula, proposed in [9], to obtain the optimal portion of sand in aggregates mix ( $\left.\mathrm{r}_{\mathrm{opt}}\right)$. In cases, when along with cement consumption and $\mathrm{W} / \mathrm{C}$ just water demand of sand is known, the crushed stone consumption can be obtained by calculating the moving apart coefficient of coarse aggregate's grains by the cement-sand mortar $\mathrm{K}_{\mathrm{s}}$ according to recommendations [6, 7]. If voidage of sand and crushed stone are known (these parameters can be easy found if true and bulk densities of aggregates are known) calculation of $K_{\mathrm{s}}$ can be done using dependencies given in [8] with corresponding corrections.

The bank of quantitative dependences available in concrete science rapidly increases during the last years especially due to polynomial regression equations - adequate mathematical models in a defined "factorial space".
The major part of these models is obtained by means of experiment planning methods [1012]. Solving concrete compositions design problems using mathematical experiment planning includes establishing relationships, between the basic concrete mix and hardened concrete properties, and factors that affect them.

At a priori study of the relationships that define the concrete properties and their qualitative structure for further mathematical modeling and optimization it is important to select the main controlled factors and to evaluate the possible curvature of the response surface in this variation region. Relatively high information level regarding the influence of composition factors and hardening regime on the basic concrete properties allows in most cases performing qualitative analysis and modeling almost immediately in the stationary region, which greatly simplifies the optimum search [13-15]. 
Multi-factorial polynomial models enable finding the optimal values of such factor; as aggregates' ratio, additives content, etc., and thus optimizing the designed concrete compositions, taking into account a given set of factors and their variation range. There are two possible approaches:

1) The optimized factors are determined from the equations, in which they are dependent variables, for example, the portion of sand in the aggregates mixture, $r$, is found from the slump or the concrete mix workability equation.

2) Equations for the optimized factors ( $r_{\text {opt }}$, superplasticizer additives, etc.) are obtained and used together with the equations of normalized parameters for design of concrete mixtures composition.

Along with differential analysis, using canonical and isoparametrical analysis as well as linear programming and alternative methods for getting optimal solutions is also possible [16-20].

\section{PURPOSE AND METHODS}

The purpose of the performed work was to solve the problem of designing the compositions of hydraulic concrete with normalized values of compressive strength, frost resistance and water impermeability. Concrete hardened under normal conditions and heat treatment by steaming.
Portland Cement Cem IIA-S with an activity of 34.5 and $47.9 \mathrm{MPa}$, respectively was used. To regulate the normal consistency of cement, an additive of superplasticizer C-3 was introduced into its composition. Quartz sand with a modulus of fineness $\mathrm{M}_{\mathrm{f}}=2.1$, granite crushed stone of fractions 5...10, $5 \ldots 40$ and $5 \ldots 70 \mathrm{~mm}$ were used as concrete aggregates. Concrete mixtures were produced both without and with the introduction of an air entraining additive like Vinsol in the amount of 0.06 and $0.12 \%$ by weight of cement.

When steaming samples, isothermal curing temperature was $80^{\circ}$. Within the overall heathumidity treatment durations of $10 \ldots 18$ hours, the preliminary curing was 3 and 5 hours, respectively. The temperature rising speed in the chamber was $15^{\circ}$ per hour.

The studies were performed using mathematical planning of experiments. The factors taken into account in the experiments and the conditions for their planning are given in Table 1.

To carry out experiments in obtaining models of entrained air, the water requirement of concrete mixes and the optimal proportion of sand in a mixture of aggregates, ensuring minimal water content, a five-factor plan $\mathrm{Ha}_{5}$ was used [16]. The properties of concrete mixes and concrete were determined in accordance with the State Standards of Ukraine (DSTU): 2.7-96: 2000, 2.7-214: 2009, 2.7-170: 2008, 2.7-46-96.

Table 1. Conditions of experiments planning

\begin{tabular}{|l|c|c|c|c|c|}
\hline \multicolumn{2}{|c|}{ Factors } & \multicolumn{3}{c|}{ Variation levels } & \multirow{2}{*}{$\begin{array}{c}\text { Variation } \\
\text { intervals }\end{array}$} \\
\hline \multicolumn{1}{|c|}{ Natural } & Coded & -1 & 0 & +1 & \\
\hline Initial water content, $\mathrm{kg} / \mathrm{m}^{3}$ & $\mathrm{x}_{1}$ & 150 & 180 & 210 & 30 \\
\hline Cement-water ratio & $\mathrm{x}_{2}$ & 1.3 & 2.1 & 2.9 & 0.8 \\
\hline Maximum crushed stone coarseness, $\mathrm{mm}$ & $\mathrm{x}_{3}$ & 10 & 40 & 70 & 30 \\
\hline Consumption of air entraining additive, $\mathrm{kg} / \mathrm{m}^{3}$ & $\mathrm{x}_{4}$ & 0 & 0.06 & 0.12 & 0.06 \\
\hline Normal cement consistency, \% & $\mathrm{x}_{5}$ & 24.6 & 27.2 & 29.8 & 2.6 \\
\hline Cement strength, MPa & $\mathrm{x}_{6}$ & 34.5 & 41.2 & 47.9 & 6.7 \\
\hline Heat-humidity treatment duration, $\mathrm{h}$. & $\mathrm{x}_{7}$ & 10 & 14 & 18 & 4 \\
\hline Conditional workability & $\mathrm{x}_{8}$ & 0 & 1 & 2 & 1 \\
\hline Normal hardening duration, days* & $\mathrm{x}_{9}$ & $\lg 28$ & $\lg 71$ & $\lg 180$ & $\lg 2.54$ \\
\hline Cement consumption, $\mathrm{kg} / \mathrm{m}^{3}$ & $\mathrm{x}_{10}$ & 234 & 378 & 522 & 144 \\
\hline
\end{tabular}

Note: * For simplification of the proper models, $\lg \tau$ was used; $\tau$ is duration of hardening, days. 
In the study of the influence of factors on the compressive strength, frost resistance and water impermeability used a six-factor plan $\mathrm{B}_{6}$ [16].

\section{EXPERIMENTAL RESULTS AND DISCUSSION}

As a result of statistical processing of experimental results, quadratic polynomial models of properties of a concrete mix and concrete were obtained (Tables $2-4$ ). Statistical analysis showed that the models obtained in the coded variables can be considered adequate with a 95\% confidence level, and the coefficients of the models are significant at the $5 \%$ significance level.

In the water consumption model (Table 2), the conditional workability values $\left(x_{8}\right)$ were planned is accordance to Table 3 .

In the model (1) of entrained air volume, instead of $\mathrm{C} / \mathrm{W}\left(x_{2}\right)$ the cement consumption $\mathrm{C}$ $\left(x_{10}\right)$ was varied (Table 1$)$.

Table 2. Mathematical models of concrete mixes' properties

\begin{tabular}{|c|c|}
\hline Properties & Equation type \\
\hline $\begin{array}{c}\text { Entrained air } \\
\text { volume, \% }\end{array}$ & $\begin{array}{l}y_{1}=2.27+0.72 x_{1}-0.63 x_{10}-0.47 x_{3}+2.14 x_{4}-0.18 x_{5}-0.20 x_{1}^{2}+0.24 x_{10}^{2}+ \\
+0.17 x_{3}^{2}-0.22 x_{4}^{2}-0.09 x_{5}^{2}-0.13 x_{1} x_{2}+0.71 x_{1} x_{4}-0.61 x_{10} x_{4}-0.46 x_{3} x_{4}-\quad(1) \\
-0.13 x_{3} x_{5}-0.19 x_{4} x_{5}\end{array}$ \\
\hline $\begin{array}{c}\text { Concrete mix } \\
\text { water consump- } \\
\text { tion, kg/m }\end{array}$ & $\begin{array}{l}y_{2}=169.2+26.4 x_{8}+13.4 x_{2}-20 x_{3}-8.3 x_{4}+9.3 x_{5}-5.2 x_{8}^{2}+5.8 x_{2}^{2}+8.8 x_{3}^{2}+ \\
+2.8 x_{4}^{2}+3.8 x_{5}^{2}+x_{8} x_{3}+2.6 x_{8} x_{5}-x_{2} x_{3}+3.1 x_{2} x_{4}+2.25 x_{2} x_{5}-1.1 x_{3} x_{5}+x_{4} x_{5}\end{array}$ \\
\hline $\begin{array}{c}\text { Optimal portion } \\
\text { of sand in ag- } \\
\text { gregates' mix }\end{array}$ & $\begin{array}{l}y_{3}=0.284+0.03 x_{1}-0.039 x_{2}-0.02 x_{3}+0.009 x_{4}+0.007 x_{1}^{2}+0.016 x_{2}^{2}+ \\
+0.008 x_{3}^{2}+0.006 x_{4}^{2}-0.005 x_{1} x_{2}+0.01 x_{1} x_{3}+0.009 x_{2} x_{4}-0.004 x_{3} x_{4}\end{array}$ \\
\hline
\end{tabular}

Table 3. Planning of conditional workability values

\begin{tabular}{|c|c|c|c|c|c|}
\hline \multirow{2}{*}{ Variation levels } & -1 & $-0,4$ & 0 & $+0,4$ & +1 \\
\hline \multirow{2}{*}{ Workability score } & \multicolumn{2}{|c|}{ Vebe time, sec } & \multicolumn{3}{|c|}{ Slump, cm } \\
\cline { 2 - 6 } & 20 & 8 & 2 & 5 & 13 \\
\hline
\end{tabular}

Table 4. Mathematical models of normal hardened concrete properties

\begin{tabular}{|l|l|}
\hline \multicolumn{1}{|c|}{ Properties } & \multicolumn{1}{|c|}{ Equation type } \\
\hline Compressive & $y_{4}=36.93-1.88 x_{8}+14.73 x_{4}-0.86 x_{5}+4.97 x_{6}+6.08 x_{9}-0.05 x_{8}^{2}-$ \\
strength, MPa & $-1.85 x_{2}^{2}-0.2 x_{4}^{2}-0.3 x_{5}^{2}+0.05 x_{6}^{2}-0.8 x_{9}^{2}-0.61 x_{8} x_{4}-0.45 x_{8} x_{5}+$ \\
& $+1.23 x_{8} x_{6}+0.97 x_{2} x_{4}-0.63 x_{2} x_{5}+2.12 x_{2} x_{6}+2.14 x_{2} x_{9}+0.99 x_{4} x_{6}-$ \\
& $-0.4 x_{5} x_{6}+0.88 x_{6} x_{9}$ \\
\hline Frost resistance, & $y_{5}=378.9-67.8 x_{8}+162.3 x_{2}+147.7 x_{4}-27.4 x_{5}+21.8 x_{6}+63.2 x_{9}+$ \\
cycles & $+9.7 x_{8}^{2}-38.8 x_{2}^{2}+6.7 x_{4}^{2}-9.8 x_{5}^{2}+11.7 x_{6}^{2}+2.2 x_{9}^{2}+29.4 x_{8} x_{2}-8.7 x_{8} x_{5}-\quad(5)$ \\
& $-16.6 x_{8} x_{9}+26.6 x_{2} x_{4}-15.8 x_{2} x_{5}+18.7 x_{2} x_{9}+7.1 x_{4} x_{6}+23.7 x_{4} x_{9}+$ \\
& $+13.8 x_{6} x_{9}$ \\
\hline Water impermeabil- & $y_{6}=0.92+0.04 x_{8}+0.56 x_{2}+0.02 x_{4}+0.01 x_{5}+0.06 x_{6}+0.25 x_{9}-$ \\
ity, MPa & $-0.05 x_{8}^{2}+0.08 x_{2}^{2}-0.01 x_{4}^{2}+0.004 x_{5}^{2}+0.03 x_{6}^{2}-0.02 x_{8} x_{2}+0.01 x_{8} x_{4}-$ \\
& $-0.02 x_{8} x_{5}+0.04 x_{2} x_{6}+0.14 x_{2} x_{9}$ \\
\hline
\end{tabular}


Table 5. Mathematical models of concrete properties after heat treatment

\begin{tabular}{|c|c|c|}
\hline Properties & Equation type & \\
\hline $\begin{array}{l}\text { Compressive strength } \\
\text { at four hours after } \\
\text { heat treatment, } \mathrm{MPa}\end{array}$ & $\begin{array}{l}y_{7}=21.98-0.93 x_{8}+10.5 x_{2}-1.03 x_{4}-1.61 x_{5}+2.32 x_{6}+2.65 x_{7}- \\
-0.49 x_{8}^{2}-0.81 x_{2}^{2}-0.09 x_{5}^{2}+0.06 x_{6}^{2}-0.96 x_{7}^{2}-2.00 x_{8} x_{2}-0.88 x_{8} x_{4}- \\
-1.36 x_{8} x_{5}-1.43 x_{8} x_{6}+2.68 x_{2} x_{6}+2.60 x_{2} x_{7}-0.91 x_{4} x_{5}-0.82 x_{4} x_{6}- \\
-1.01 x_{4} x_{7}+1.18 x_{5} x_{7}+1.22 x_{6} x_{7}\end{array}$ & (7) \\
\hline $\begin{array}{l}\text { Compressive strength } \\
\text { at } 28 \text { days after heat } \\
\text { treatment, } \mathrm{MPa}\end{array}$ & $\begin{array}{l}y_{8}=30.6-2.24 x_{8}+13.03 x_{2}-2.86 x_{4}-0.99 x_{5}+3.97 x_{6}+1.94 x_{7}- \\
-0.05 x_{8}^{2}-1.75 x_{2}^{2}-0.5 x_{4}^{2}-0.35 x_{5}^{2}+0.1 x_{6}^{2}-0.2 x_{7}^{2}-1.29 x_{8} x_{2}+ \\
+1.18 x_{2} x_{4}-0.63 x_{2} x_{5}+2.71 x_{2} x_{6}+0.97 x_{2} x_{7}\end{array}$ & (8) \\
\hline $\begin{array}{l}\text { Frost resistance, cy- } \\
\text { cles }\end{array}$ & $\begin{array}{l}y_{9}=281.9-38.3 x_{8}+145.4 x_{2}+89.2 x_{4}-16 x_{5}+17.7 x_{7}+8.3 x_{8}^{2}- \\
-15.7 x_{2}^{2}-12.2 x_{4}^{2}-5.2 x_{5}^{2}+9.3 x_{6}^{2}-2.2 x_{7}^{2}-13.3 x_{8} x_{2}+14.8 x_{8} x_{4}+ \\
+7.3 x_{2} x_{4}+21.2 x_{6} x_{7}\end{array}$ & (9) \\
\hline $\begin{array}{l}\text { Water impermeability, } \\
\mathrm{MPa}\end{array}$ & $\begin{array}{l}y_{10}=0.57+0.07 x_{8}+0.43 x_{2}+0.03 x_{5}+0.06 x_{6}+0.05 x_{7}- \\
-0.02 x_{8}^{2}+0.08 x_{2}^{2}+0.02 x_{4}^{2}-0.06 x_{7}^{2}+0.07 x_{8} x_{2}+0.03 x_{8} x_{4}- \\
-0.04 x_{2} x_{4}+0.03 x_{2} x_{5}-0.06 x_{2} x_{6}-0.02 x_{4} x_{6}- \\
-0.02 x_{4} x_{7}+0.01 x_{5} x_{6}+0.02 x_{6} x_{7}\end{array}$ & (10) \\
\hline
\end{tabular}

Using a complex of polynomial models allow a relatively easy solution of the concrete composition optimization problem in a wide range of given parameters of properties. The essence of the method is that models $y_{4}, y_{5}, y_{6}$ or $y_{7}, y_{8}, y_{9}, y_{10}$ are solved regarding $\mathrm{C} / \mathrm{W}$, whereas other factors are fixed at required levels and the values of necessary strength, frost resistances and water impermeability are given. $\mathrm{C} / \mathrm{W}$, providing all the required properties, is found. Then the water consumption and the optimal portion of sand in the mixture of aggregates are found using $\mathrm{y}_{2}$ and $\mathrm{y}_{3}$ models. After that, cement, sand and crushed stone contents per $1 \mathrm{~m}^{3}$ of concrete mixture are calculated using the absolute volumes method.

\section{Example 1. Design the hydraulic concrete} composition without air-entraining admixture used in structures at 28 days of normal hardening.

Nomograms shown in Figs.2, 3 and 4 were created to simplify calculations, performed using the mathematical models (Tables $2-4$ ). These nomograms can be used to determine the water content, $\mathrm{C} / \mathrm{W}$ and $\mathrm{r}$ for given conditions. The established approximate relations of normal hardening concrete properties (Table 6) are used.

Additionally, a nomogram for determining the portion of sand in the aggregates' mix
(Fig.3) is corrected, taking into account experimental results, characterizing the influence of sand fineness modulus.

For example, Portland cement with strength of $40 \mathrm{MPa}\left(\rho_{\mathrm{c}}=3,1 \mathrm{~kg} / l\right.$, paste normal consistency $\mathrm{NC}=28 \%$ ), quartz sand (fineness modulus $\left.\mathrm{M}_{\mathrm{f}}=2.2, \rho_{\mathrm{s}}=2,6 \mathrm{~kg} / l\right)$, crushed granite of fraction $5 \ldots 20 \mathrm{~mm}\left(\rho_{\text {cr.s }}=2,65 \mathrm{~kg} / l\right)$ and admixture of technical lignosulphonates 0.25 $\%$ (LST) by cement weight are used for production of concrete with minimum 28-days compressive strength $25 \mathrm{MPa}$, frost resistance of 150 freezing and thawing cycles and water impermeability of $0.2 \mathrm{MPa}$ in an age of 28 days, the concrete mixture's slump should be $1 \ldots 2 \mathrm{~cm}$. Water reducing effect of additive LST $-8 \%$.

According to Table 6, the ultimate concrete strength, providing the required frost resistances and water impermeability, is $R_{\mathrm{cmp}}=$ $30 \mathrm{MPa}$ ).

Following Fig.2, the required cement-water ratio: $\mathrm{C} / \mathrm{W}=1.96$.

Water content (Fig.3) is $190 \mathrm{~kg} / \mathrm{m}^{3}$, and considering admixture of LST W $=190 \cdot 0.92$ $=175 \mathrm{~kg} / \mathrm{m}^{3}$.

Content of cement: $\mathrm{C}=175 \cdot 1.96=343 \mathrm{~kg} / \mathrm{m}^{3}$.

The optimal portion of sand in the aggregates' mix is obtained using Fig. $4: r=0.345$.

Content of sand (S) and crushed stone (Cr.S) are: 
$S=\left[1000-\left(\frac{343}{3.1}+\frac{175}{1.0}\right)\right] \cdot 0.345 \cdot 2.6=641 \mathrm{~kg} / \mathrm{m}^{3}, \quad C r . S=\left[1000-\left(\frac{343}{3.1}+\frac{175}{1.0}+\frac{641}{2.6}\right)\right] \cdot 2.65=1240 \mathrm{~kg} / \mathrm{m}^{3}$

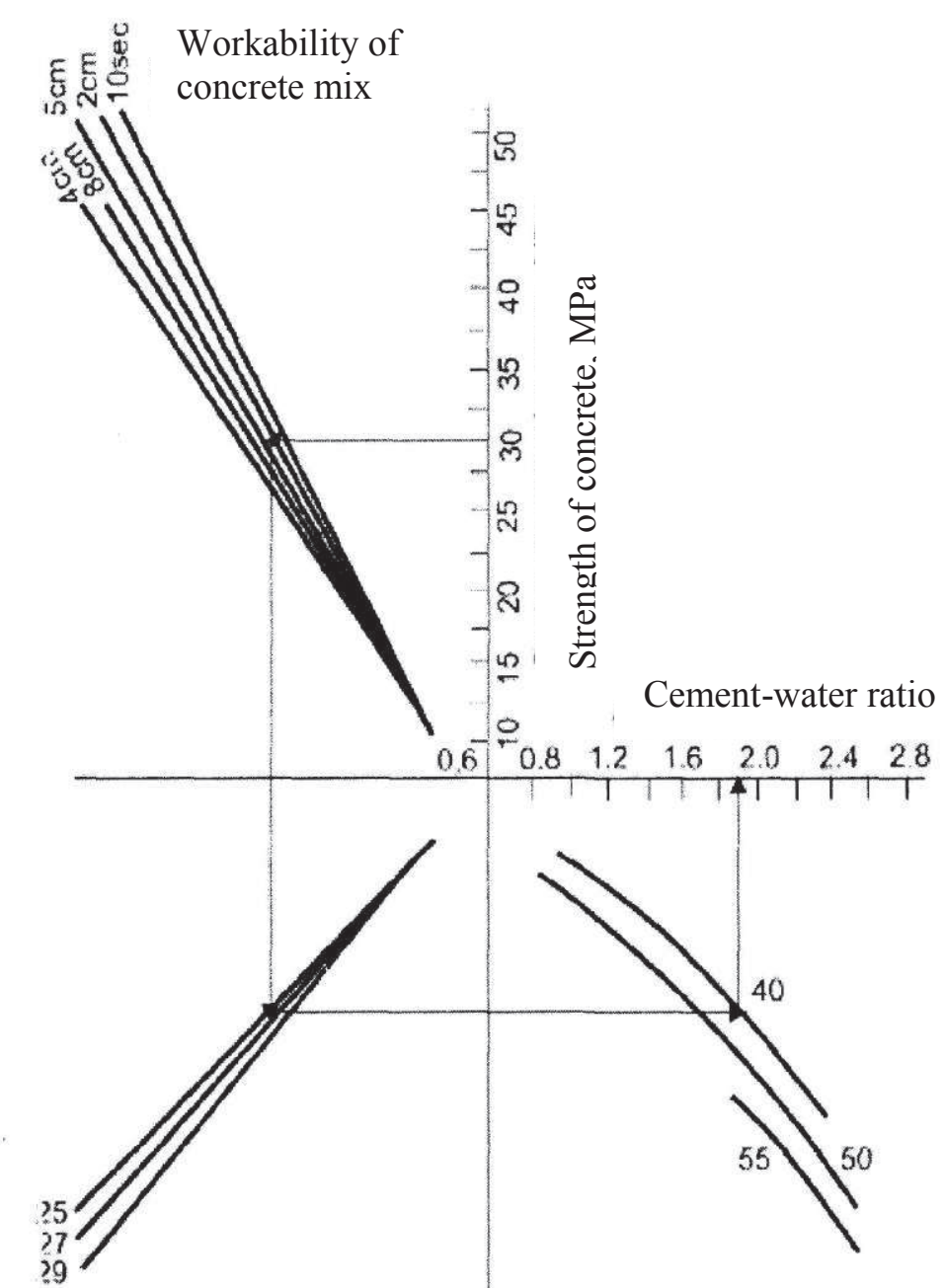

Cement paste consistency, \%

Cement strength, MPa

Fig.2. Nomogram for determining the cement-water ratio for concrete at 28 days (without air-entraining admixture)

Table 6. Relations between properties of normal hardened concrete without air entraining admixtures

\begin{tabular}{|c|c|c|c|}
\hline \multirow{2}{*}{ Mix slump, cm } & \multicolumn{3}{|c|}{ Concrete strength } \\
\cline { 2 - 4 } & \multicolumn{3}{|c|}{28 days } \\
\cline { 2 - 4 } & Strength, MPa & Frost resistance, cycles & Water impermeability, MPa \\
\hline $1 \ldots 4$ & 20 & $50 \ldots 75$ & 0.2 \\
\hline $5 \ldots 9$ & 20 & $50 \ldots 75$ & 0.2 \\
\hline $10 \ldots 15$ & 20 & 50 & 0.2 \\
\hline $1 \ldots 4$ & 30 & $100 \ldots 150$ & $0.2 \ldots 0.4$ \\
\hline $5 \ldots 9$ & 30 & 100 & $0.2 \ldots 0.4$ \\
\hline $10 \ldots 15$ & 30 & $75 \ldots 100$ & $0.2 \ldots 0.4$ \\
\hline $1 \ldots 4$ & 40 & $200 \ldots 250$ & $0.6 \ldots 0.8$ \\
\hline $5 \ldots 9$ & 40 & $200 \ldots 250$ & $0.6 \ldots 0.8$ \\
\hline $10 \ldots 15$ & 40 & $100 \ldots 150$ & $0.6 \ldots 0.8$ \\
\hline
\end{tabular}




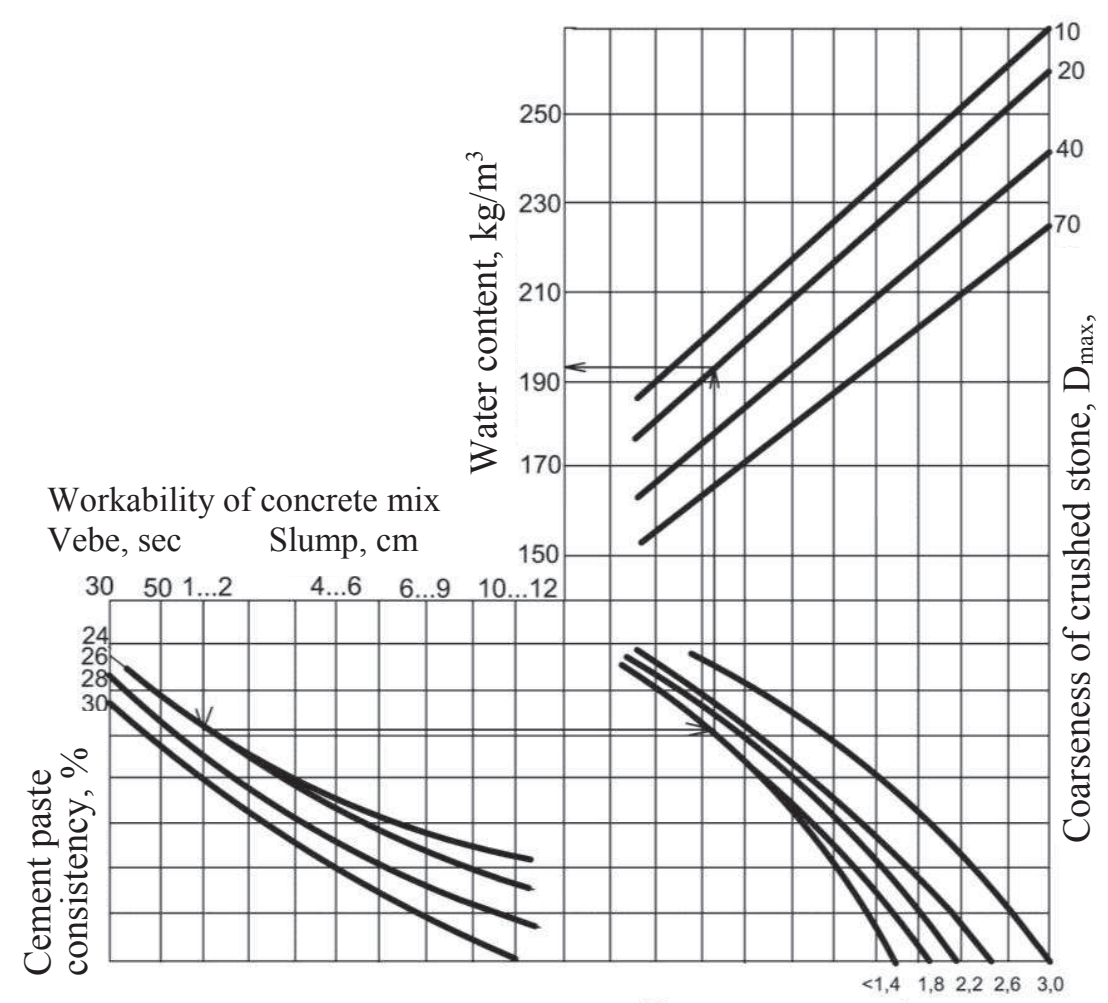

Cement-water ratio

Fig.3. Nomogram for determining water consumption of concrete mixtures

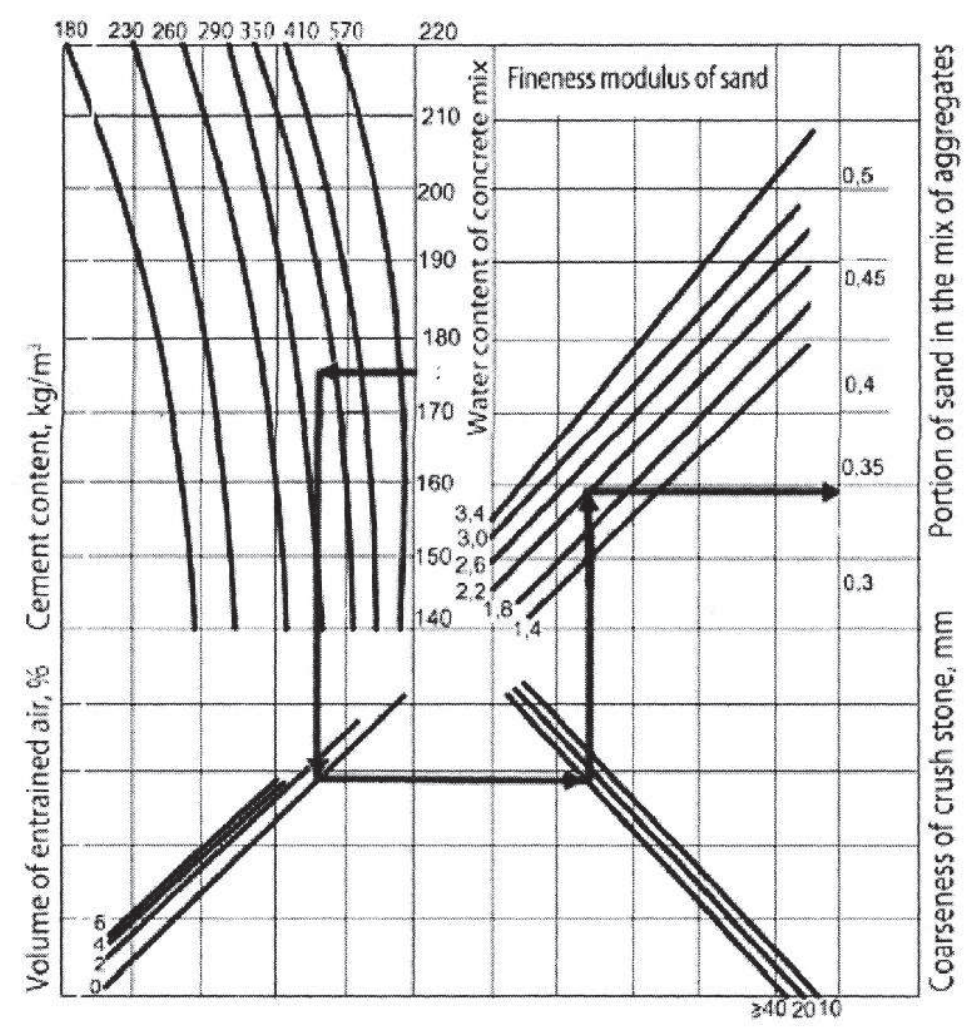

Fig.4. Nomogram for determınıng the portion ot sand in aggregates' mix 
Example 2. Design a composition of hydraulic concrete with different values of strength after heat treatment.

A complex of mathematical models (Table 5) enables finding solutions of such problems for any strength after heat treatment, changing the overall heat process duration, mixes workability and cement paste normal consistency in a wide range.

The algorithm for solving this problem differs from the previous just by the fact that either the model for ultimate strength $\mathrm{y}_{8}$ at 28 days after heat treatment for the strength at four hours after heat treatment $\mathrm{y}_{7}$ are solved for finding $\mathrm{C} / \mathrm{W}$. To determine the cement content, the higher over the two cement-water ratios are selected.

Fig. 5 represents a nomogram for finding the $\mathrm{C} / \mathrm{W}$ ratio that providing the ultimate strength and the required concrete mix workability for a given strength after heat treatment. The approximate steamed concrete properties relations and are given in Tables 7.
For example, for concrete with required compressive strength of $20 \mathrm{MPa}$, frost resistance F150 and heat treatment duration of 18 hours, the strength after steaming should be $70 \%$ of the 28-day one and the concrete mix slump is $1 \ldots 4 \mathrm{~cm}$. Portland cement with strength of $40 \mathrm{MPa}$ (paste normal consistency $\left.\mathrm{NC}=28 \%, \rho_{\mathrm{c}}=3.1 \mathrm{~kg} / \mathrm{l}\right)$, quartz sand with fineness modulus $\mathrm{M}_{\mathrm{f}}=2.2\left(\rho_{\mathrm{s}}=2.6 \mathrm{~kg} / \mathrm{l}\right)$, crushed granite stone fraction $5 \ldots 40 \mathrm{~mm}\left(\rho_{\text {cr.s }}\right.$ $=2.65 \mathrm{~kg} / \mathrm{l}$ ) are used.

Following Table 7, for providing the required frost resistance of 150 freezing and thawing cycles, the 28 days concrete compressive strength should be $25 \mathrm{MPa}$.

According to Fig.5, the required $\mathrm{C} / \mathrm{W}=1.7$. The water content (Fig. 2) is $190 \mathrm{~kg} / \mathrm{m}^{3}$. The required cement content:

$$
C=190 \cdot 1.7=323 \mathrm{~kg} / \mathrm{m}^{3} \text {. }
$$

The optimal sand portion in the aggregates' mix is found using Fig.4: $r=0.38$.

Table 7. Relations between properties of concrete without air entraining admixtures, subjected to heat treatment (duration of $14 \ldots 18$ hours)

\begin{tabular}{|c|c|c|c|}
\hline $\begin{array}{c}\text { Concrete compres- } \\
\text { sive strength at } 28 \\
\text { days, MPa }\end{array}$ & $\begin{array}{c}\text { Strength after } \\
\text { steaming, \% of that } \\
\text { at } 28 \text { days }\end{array}$ & Frost resistance, cycles & Water impermeability, MPa \\
\hline 15 & 70 & Less than 50 & 0.2 \\
\hline & 100 & $50 \ldots 100$ & 0.2 \\
\hline 20 & 50 & Less than 50 & 0.2 \\
& 70 & $50 \ldots 100$ & $0.2 \ldots 0.4$ \\
25 & 100 & $100 \ldots 150$ & $0.4 \ldots 0.6$ \\
\hline & 50 & $50 \ldots 100$ & $0.2 \ldots 0.4$ \\
& 70 & $100 \ldots 150$ & $0.4 \ldots 0.6$ \\
& 100 & $200 \ldots 250$ & 0.6 \\
\hline & 50 & $75 \ldots 100$ & $0.4 \ldots 0.4$ \\
& 70 & $150 \ldots 200$ & $0.6 \ldots 0.8$ \\
\hline & 100 & $200 \ldots 250$ & $0.4 \ldots 0.6$ \\
& 50 & $100 \ldots 200150 \ldots 250$ & $0.6 \ldots 0.8$ \\
& 70 & $200 \ldots 300$ & $0.8 \ldots 1.0$ \\
\hline & 100 & $150 \ldots 250$ & $0.6 \ldots 0.8$ \\
& 50 & $200 \ldots 300$ & $0.8 \ldots 1.0$ \\
\hline & 70 & 300 & $1.0 \ldots 1.2$ \\
\hline
\end{tabular}

Note: Minimal frost resistance and water impermeability values are given for mixes with slump of $10 \ldots 15 \mathrm{~cm}$, and maximal values - for mixes with slump $1 \ldots 4 \mathrm{~cm}$ 


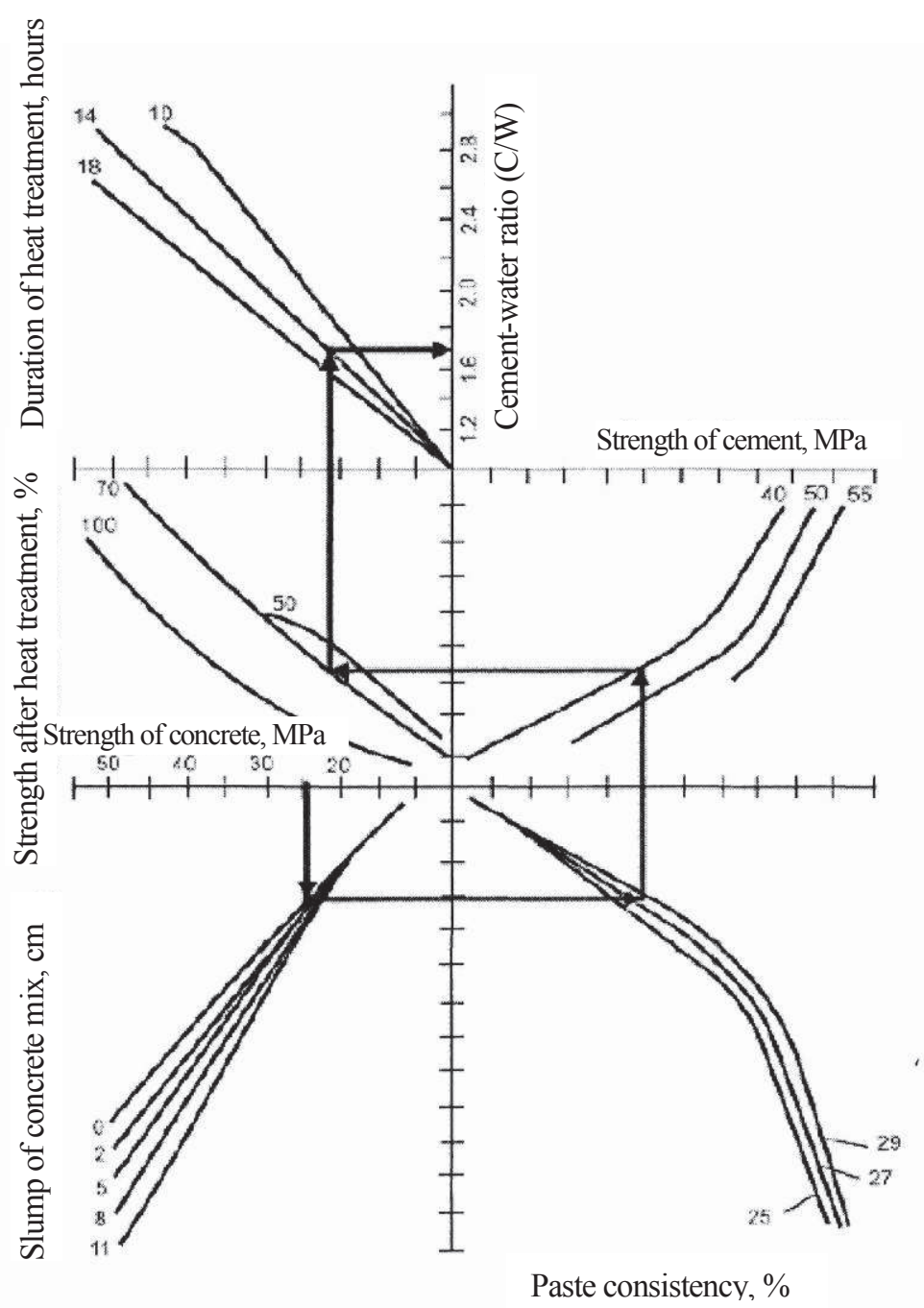

Fig.5. Nomogram for determining the cement-water ratio for concrete after heat treatment

Consumptions of sand and crushed stone are:

$$
\begin{aligned}
& S=\left[1000-\left(\frac{323}{3.1}+\frac{190}{1}\right)\right] \cdot 0.38 \cdot 2.6=697 \mathrm{~kg} / \mathrm{m}^{3} \\
& C r . S=\left[1000-\left(\frac{323}{3.1}+\frac{190}{1}+\frac{697}{2.6}\right)\right] \cdot 2.65=1160 \mathrm{~kg} / \mathrm{m}^{3}
\end{aligned}
$$

Example 3. Design compositions of hydraulic concrete with air entraining admixture for the conditions described in Example 1.

Figs. 6 and 7 are given nomograms that can be used for calculating $\mathrm{C} / \mathrm{W}$ and the airentraining admixture's content, required for providing the given properties' complex.
Tables 8 presents the optimal content of the entrained air for concrete with different properties. Water content, obtained using Fig.2, is corrected taking into account the entrained air volume.

Following Table 8, the entrained air volume for the given concrete design requirements should be $2.5 \%$. The $\mathrm{C} / \mathrm{W}$ ratio providing the compressive strength of $20 \mathrm{MPa}$ according to Fig.1 is 1.5. Following Fig.6, the $\mathrm{C} / \mathrm{W}$ value, corresponding to the optimal air content for the given design properties, is 1.65. For further calculations the $\mathrm{C} / \mathrm{W}$ is assumed to be equal to 1.65 . 
Table 8. Entrained air volume for concrete with different design requirements

\begin{tabular}{|c|c|c|c|}
\hline \multicolumn{3}{|c|}{ Concrete properties } & \multirow{2}{*}{$\begin{array}{l}\text { Required volume of } \\
\text { entrained air, \% }\end{array}$} \\
\hline $\begin{array}{c}\text { Strength at } 28 \text { days, } \\
\mathrm{MPa}\end{array}$ & $\begin{array}{c}\text { Frost resistance, } \\
\text { cycles }\end{array}$ & $\begin{array}{c}\text { Water impermeability, } \\
\mathrm{MPa}\end{array}$ & \\
\hline 20 & $\begin{array}{l}100 \\
150 \\
200 \\
300\end{array}$ & $\begin{array}{c}0.4 \\
0.4 \ldots 0.6 \\
0.4 \ldots 0.6 \\
0.4 \ldots 0.6\end{array}$ & $\begin{array}{l}1.5 \ldots 2.0 \\
2.5 \ldots 3.0 \\
3.0 \ldots 3.5 \\
3.5 \ldots 4.0\end{array}$ \\
\hline 30 & $\begin{array}{l}200 \\
300 \\
400\end{array}$ & $\begin{array}{c}0.6 \\
0.6 \ldots 0.8 \\
0.6 \ldots 0.8\end{array}$ & $\begin{array}{l}1.5 \ldots 2.0 \\
2.5 \ldots 3.0 \\
3.5 \ldots 4.0\end{array}$ \\
\hline 40 & $\begin{array}{l}300 \\
400 \\
500\end{array}$ & $\begin{array}{l}0.8 \ldots 1.0 \\
0.8 \ldots 1.0 \\
1.0 \ldots 1.2\end{array}$ & $\begin{array}{l}3.0 \ldots 3.5 \\
3.5 \ldots 4.0 \\
4.5 \ldots 5.0\end{array}$ \\
\hline
\end{tabular}

Note: Minimal and maximal values of entrained air volume are given for mixes with slump of $1 \ldots 4 \mathrm{~cm}$ and $10 \ldots 15 \mathrm{~cm}$, respectively.

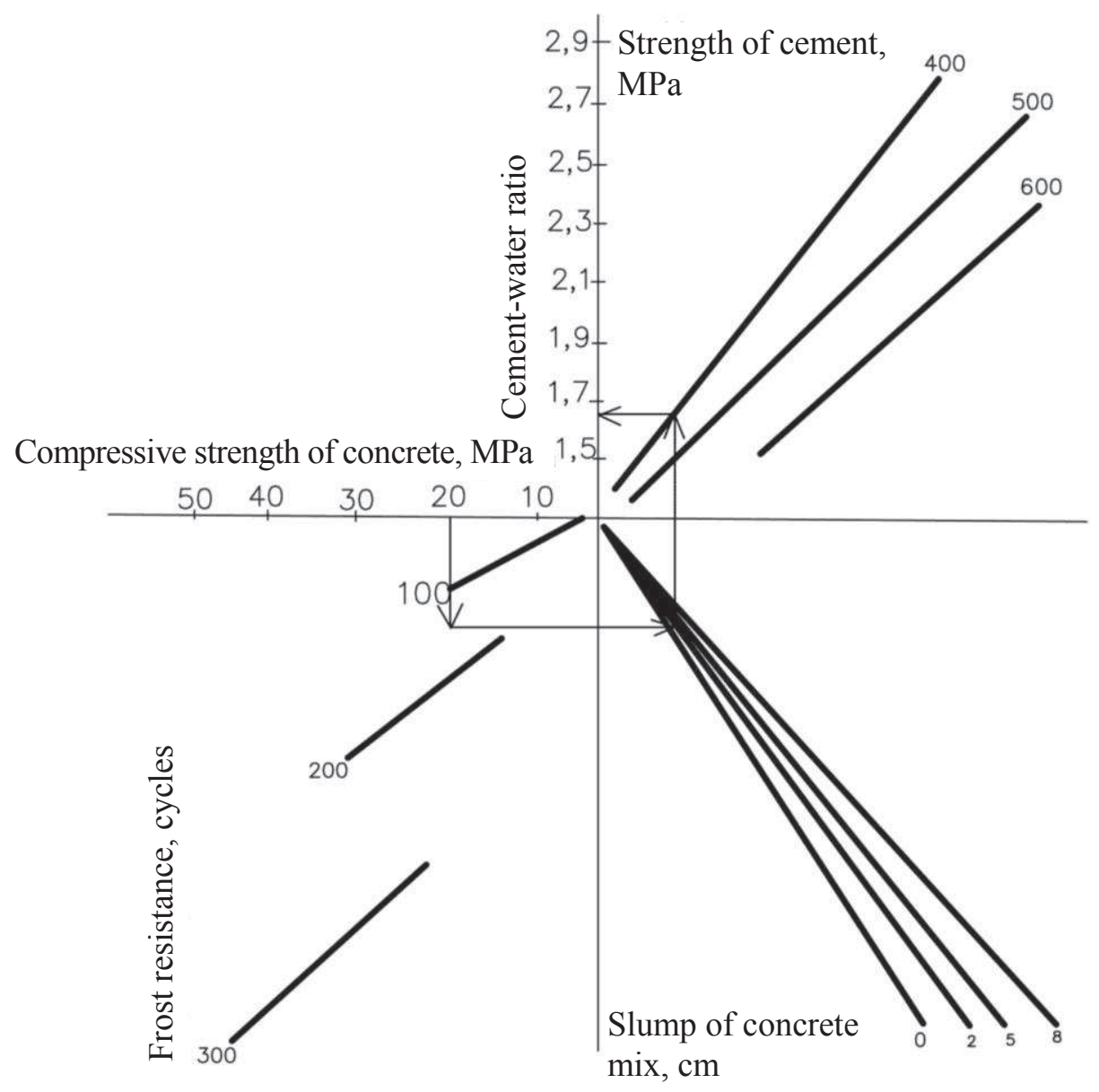

Fig.6. A nomogram for determining the $\mathrm{C} / \mathrm{W}$ ratio for concretes with optimal entrained air content 


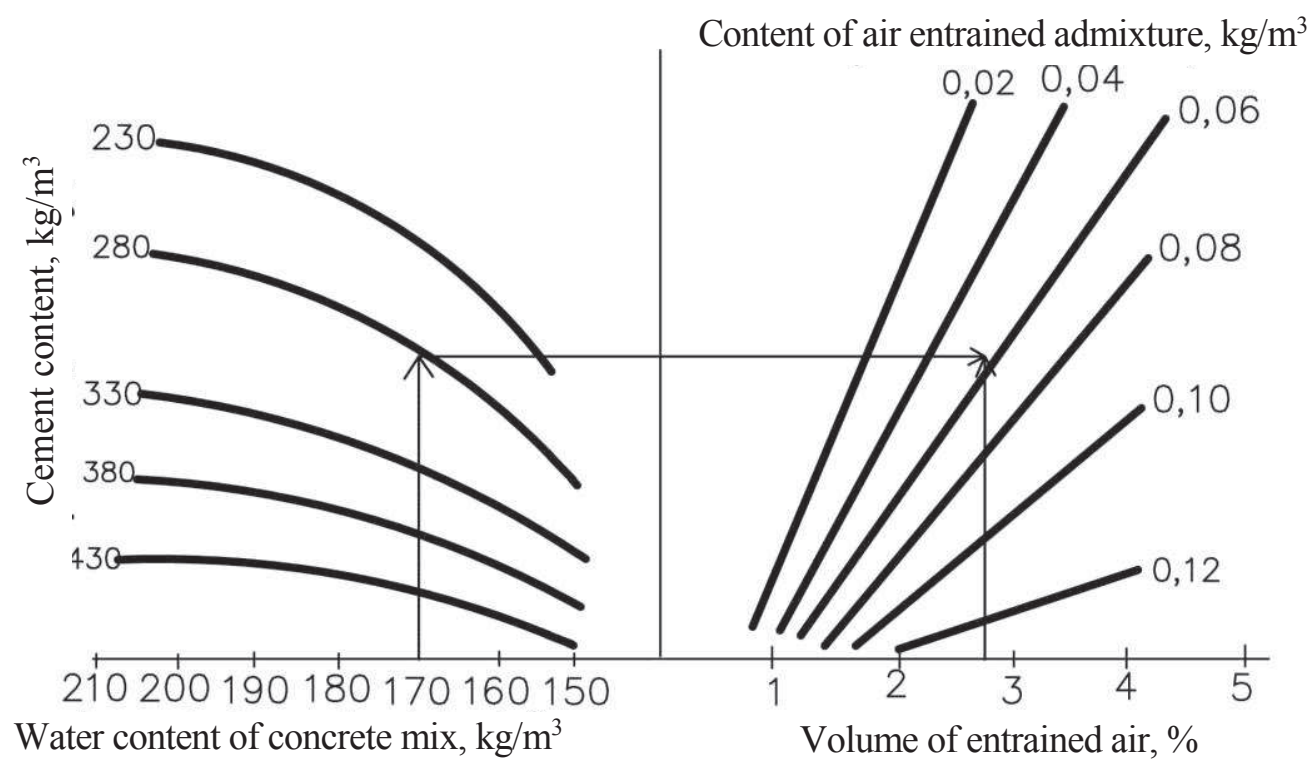

Fig.7. A nomogram for defining the air-entraining content

The optimal portion of sand in the aggregates' mix is obtained using Fig.4: $r=0.36$.

Sand and crushed stone content are obtained taking into account the entrained air volume:

$$
\begin{aligned}
& S=\left[1000-\left(\frac{297}{3.1}+\frac{180}{1}+25\right)\right] \cdot 0.36 \times \\
& \times 2.6=654 \mathrm{~kg} / \mathrm{m}^{3}
\end{aligned}
$$$$
C r . S=\left[1000-\left(\frac{297}{3.1}+\frac{180}{1}+25+\frac{654}{2.6}\right)\right] \times
$$$$
\times 2.65=1186 \mathrm{~kg} / \mathrm{m}^{3}
$$

The content of air entrained admixture equals $0.05 \mathrm{~kg} / \mathrm{m}^{3}$ (Fig.7).

\section{CONCLUSIONS}

1. Considered methodological principles for solving problems of multiparameter design of concrete compositions (MPCCD). A general block schema is presented for solving composite tasks of the MPCCD to determine the specific consumptions of components that provide a given set of proper ties of concrete and compositional-technological tasks with the goal of additional determining the value of technological factors that characterize the conditions of production and hardening of concrete.

2. With the use of mathematical methods of planning experiments, a set of experimentalstatistical models and nomograms on their basis were obtained with the help of which examples of determining the compositions of hydraulic concrete with given parameters of strength, frost resistance and water impermeability of concrete hardening under normal hardening and heat-moisture treatment were solved both for concrete mix with and without air entraining additives.

\section{REFERENCES}

1. Dvorkin L.I., 1981. Optimal design of concrete compositions. Lvov, Vyshcha shkola, 159 (in Ukrainian).

2. Dvorkin L.I, Dvorkin O.L, Ribakov Y., 2012. Mathematical experiments planning in concrete technology. New York, Nova Science Publishers, 173.

3. Voznesenskiy V.A., Lyashenko T.V., Ogarkov B.L., 1989. Numerical methods for solving problems of construction technology using 
computers. Kiev, Vyshcha shkola, 328 (in Russian).

4. Singiresu S. Rao., 1996. Engineering optimization. Theory and Practice. 3-rd edition, WileyInterscience, 920.

5. Dvorkin L.I, Dvorkin O.L, Ribakov Y., 2013. Multi-Parametric Concrete Compositions Design. New York, Nova Science Publishers, Inc., 223.

6. Bazhenov Y.M., 1987. Concrete technology. Moscow, Vysshaya shkola, 449 (in Russian).

7. Skramtayev B.G., Shubenkin P.F., Bazhenov Y.M., 1966. Methods for proportioning different types of concrete compositions. Moscow, Stroyizdat, 159 (in Russian).

8. Sizov V.P., 1980. Design of normal-weight concrete compositions. Moscow, Stroyizdat, 144 (in Russian).

9. Shmigalskiy V.N., 1981. Optimization of cement concrete compositions. Chisinau, Shtinca, 123 (in Russian).

10.Dvorkin L.I, Dvorkin O.L, Ribakov Y., 2012. Mathematical experiments planning in concrete technology. New York, Nova Science Publishers, 173.

11.Dvorkin L.I., Dvorkin O.L., Korneychuk Yu.A., 1995. Effective Cement-Ash Concrete. Rivne, Eden Publishers, 195 (in Russian).

12.Dvorkin L.I., Dvorkin O.L., 2016. Ectimated Properties Prediction and Design of Concrete Compositions. Moscow, Infra-Engineering, 384 (in Russian).

13.Dvorkin L.I, Dvorkin O.L., 2006. Basics of concrete science. St.-Petersburg, Stroybeton, 686 (in Russian).

14.Pihlajavaara S., Paroll H., 1975. On the correlation between permeability properties and strength of concrete. Cement and Concrete research, Vol.5, 321-328.

15.Ivanov F.M., Krasnovskaya T.G., Solntseva V.L., 1968. Affect of thermal-humid curing on structure and properties of cement mortars. Proceedings of International conference on problems of accelerating concrete hardening at producing precast reinforced concrete elements. Moscow, 25-32 (in Russian).

16.Voznesenskiy V.A., Lyashenko T.V., Ogarkov B.L., 1989. Numerical methods for solving problems of construction technology using computers. Kyiv, Vyshcha shkola, 328 (in Russian).

17.Gordon S.S., 1969. Structure and properties of normal-weight concrete with different aggregates. Moscow, Stroyizdat, 151 (in Russian).
18.Reibman N.S., Chadeev V.M., 1975. Creating models for industrial processes. Moscow, Energiya, 375 (in Russian).

19.Batrakov V.G., 1990. Modified concretes. Moscow, Stroyizdat, 396 (in Russian).

20.Dvorkin L.I., Dvorkin O.L., 1998. Industrial adaptation of calculated concrete compositions. Beton i zhelezobeton, Moscow, No.6, 10-11 (in Russian).

\section{Расчет составов гидротехнического бетона с использованием экспериментально- статистических моделей \\ Леонид Дворкин}

Аннотация. В статье рассматриваются особенности и общие методологические принципы решения задач многопараметрического проектирования составов бетона с помощью экспериментально-статистических моделей, полученных с применением математического планирования экспериментов.

Даны примеры решения задач оптимизации составов гидротехнического бетона с нормируемыми параметрами прочности, морозостойкости и водонепроницаемости. Приводятся полиномиальные модели заданных свойств бетонной смеси и бетона в зависимости от основных технологических факторов адекватные в принятом фактором пространстве с учетом особенностей исходных материалов. На основе полученных моделей построены номограммы, позволяющие выполнить численный анализ моделей и необходимые технологические расчеты. С использованием приведенных номограмм рассчитаны составы бетонов, обеспечивающие заданные свойства бетона в условиях нормального твердения и тепловой обработки. Определено также влияние длительности твердения и содержания вовлеченного воздуха для бетонов различных составов.

Ключевые слова: гидротехнический бетон, прочность, морозостойкость, водонепроницаемость, математические модели. 